\title{
Edukacyjny potencjał książek obrazkowych na przykładzie twórczości Iwony Chmielewskiej
}

\begin{abstract}
Streszczenie
Celem tekstu jest zaprezentowanie edukacyjnego potencjału wybranych książek Iwony Chmielewskiej - polskiej artystki, ilustratorki, grafika. Zwrócono uwagę na treści wybranych prac autorki, które można traktować jako narzędzia sprzyjające nade wszystko pracy nad rozwojem wyobraźni i empatii czytelników. Analizując całą architekturę wybranych książek obrazkowych toruńskiej artystki, można je postrzegać jako nieograniczone pole mogące służyć projektowaniu „okazji edukacyjnych”, mając na uwadze maksymalizowanie szans rozwojowych dzieci, szczególnie w młodszym wieku szkolnym. Tekst jest pomysłem wyjścia do dzieci z książką artystyczną, zachętą do poszukiwania innych o podobnym bogactwie metafor i symboli, tak aby tego typu literatura stała się przedmiotem różnych form edukacji szkolnej i pozaszkolnej. Tekst ma następującą strukturę: wyjaśnienie rozumienia terminu „książka obrazkowa” (angielska nazwa picturebook); podkreślenie znaczenia picturebooków w kulturze współczesnej; próba określenia charakterystycznego stylu książek Iwony Chmielewskiej; rozważania nad znaczeniem empatii i wyobraźni dla kulturowego uwrażliwiania czytelnika; przedstawienie propozycji działań edukacyjnych zainspirowanych książkami Iwony Chmielewskiej. Wykorzystano metodę analizy treści stosowaną w metodologii badań jakościowych.
\end{abstract}

1 Anna Józefowicz, Wydział Nauk o Edukacji, Uniwersytet w Białymstoku, Polska, e-mail: a.jozefowicz@uwb.edu.pl, ORCID ID: htpps://orcid.org/0000-0001-9126-3874. 


\title{
Słowa kluczowe:
}

książka obrazkowa (picturebook), Iwona Chmielewska, czytanie dialogowe, edukacja, dziecko, empatia, wyobraźnia

\begin{abstract}
The aim of the text is to present the educational potential of selected books by Iwona Chmielewska - a Polish artist, illustrator, graphic artist. The attention was paid to the content of selected works by the author, which can be treated as tools conducive to work on the development of readers' imagination and empathy. By analyzing the entire architecture of selected picture books by Chmielewska, they can be seen as an unlimited field that can be used to design „educational opportunities”. The text is an idea of going out to children with an art book, an encouragement to look for others with a similar wealth of metaphors and symbols, so that this type of literature becomes the subject of various forms of school and extracurricular education. The text is structured as follows: explain the meaning of the term picture book; emphasizing the importance of picturebooks in contemporary culture; an attempt to define the characteristic style of Iwona Chmielewska's books; consider the importance of empathy and imagination for the cultural sensitization of the reader; presenting proposals for educational activities inspired by the books by Iwona Chmielewska. The content analysis method used in the methodology of qualitative research was used.
\end{abstract}

\section{Keywords:}

picturebook, Iwona Chmielewska, dialogue reading, education, child, empathy, imagination

\section{KSIĄŻKI OBRAZKOWE SZANSĄ DZIECKA NA SPOTKANIE ZE SZTUKĄ}

Przez książkę obrazkową (w literaturze anglojęzycznej określaną picturebookiem) „(...) rozumie się specyficzny gatunek sztuki dla dzieci skonstruowany jako spójny tekst kulturowy, który dzięki silnej współzależności dwu modalności - tekstowej i wizualnej opowiada historię (książka narracyjna) albo przedstawia i opisuje proste idee, przedmioty, czynności (książka nienarracyjna, w języku angielskim trafnie zwana early - concept book)” (Cackowska, 2016, s. 103). Istotą książki obrazkowej są różnorodne relacje pomiędzy obrazem i tekstem. Obraz funkcjonuje z testem na równych prawach, „(...) ważnym aspektem książki obrazowej jest kreowanie jej przez artystę jako dzieła sztuki dla odbiorcy i jego doświadczenia estetycznego” (Cackowska, 2017, s. 24). Ilustracja w książce jest często pierwszą 
szansą spotkania dziecka ze sztuką. Według Barbary Bader, jednej z pierwszych badaczek picturebooka na świecie, jest to całościowy projekt, forma sztuki opierająca się na współzależności obrazów i słów, jednoczesnym wyświetlaniu dwóch sąsiadujących stron oraz dramatyzmie ich przewracania (Bader, 1976). To gatunek hybrydalny, funkcjonujący na pograniczu wielu sztuk, sięgający po metaforę, integrujący słowo i obraz w skomplikowane relacje, których odczytanie wymaga uważności, zaangażowania, a nade wszystko pracy wyobraźni.

W literaturze przedmiotu można spotkać się takimi określeniami książki obrazowej, jak: ikonotekst ${ }^{2}$ - pojęcie odnoszące się do niepodzielnej jedności obrazu i słowa, artefakt kulturowy (Cackowska, 2017, s. 11-48), książka integralna, zakładającą wkład odbiorcy w swoje pełne istnienie, artystyczna, minimalistyczna, myśląca, wielopoziomowa.

O picturebooku można powiedzieć, że jest zjawisko nierozerwalnie związane z charakterem współczesnej cywilizacji, odpowiedź na zmieniającą się rzeczywistość i przemiany społeczne. To gatunek wciąż ewaluujący, wypływający z zaskakujących nieraz poszukiwań twórczych współczesnych artystów będących często równocześnie grafikami, ilustratorami, prozaikami czy poetami. Podstawową funkcją książek obrazkowych jest rozwijanie wrażliwości estetycznej dzieci, rozbudzanie wyobraźni, kształtowanie abstrakcyjnego myślenia. Książka obrazkowa, jako medium coraz częściej zaangażowane w podejmowanie tematów trudnych, tabu, rozwija się bardzo intensywnie, podobnie jak poświęcone jej w różnych kontekstach badania naukowe ${ }^{3}$. Niestety szkolna lista lektur nie zawiera tytułów książek obrazkowych, choć wiele z tego rodzaju publikacji mogłoby być doskonałym materiałem edukacyjnym i wychowawczym na poziomie klas I-III szkoły podstawowej.

${ }^{2}$ Ikonotekst (iconotext) - pojęcie wprowadzone przez szwedzką badaczkę Kirstin Hallberg w 1982 roku, odnoszące się do niepodzielnej jedności obrazu i słowa. Termin ten został spopularyzowany przez Carole Scott i Marię Nikolajevą w książce How picturebooks work, Routledge, Londyn 2006.

3 Wybrane badania nad książką obrazkową: Bader, B. (1976). American picturebooks from Noah's Ark to the Beast Within, New York: Macmillan; Arzipe, E., Styles M. (2003). Children Reading Pictures. Interpreting visual texts. New York London: Routledge Taylor \& Francis Group; Nikolajeva, M., Scott C. (2006). How picturebooks work. New York London: Routledge Taylor \& Francis Group; Postmodern Picturebooks. Play, Parody, and Self-Referentiality. (2008). New York London: Routledge Taylor \& Francis Group; Emergent Literacy. Children's Books from 0 to 3 (2011). B. Kummerling - Meibauer (red.). Amsterdam \& Philadelphia: John Benjamins Publishing Company; Ksiqż̇ka obrazkowa. Wprowadzenie. (2017). M. Cackowska, H. Dymel - Trzebiatowska, J. Szyłak (red.). Poznań: Instytut Kultury Popularnej. 


\section{NIESKOŃCZONE MOŻLIWOŚCI INTERPRETACYJNE OBRAZKOWYCH KSIĄŻEK IWONY CHMIELEWSKIEJ}

Iwona Chmielewska jest polską ilustratorką, artystą grafikiem, autorką książek dla dzieci i dorosłych. Ukończyła grafikę na Wydziale Artystycznym Uniwersytetu im. Mikołaja Kopernika. Jej aktorskie książki obrazkowe, zwane artystycznymi projektami, są wydawane w wielu krajach na świecie (Chiny, Korea Południowa, Tajwan, Japonia, Meksyk) i są honorowane licznymi międzynarodowymi wyróżnieniami ${ }^{4}$.

Autorskie projekty artystki można określić „książkami gościnnymi”, a więc otwartymi na wielostronne odczytania, aktywizującymi twórczo, zapraszającymi do rozstrzygania ważnych społecznie kwestii (m.in.: ubóstwa, choroby, wojny) ukrytych w niedomówieniach, sugerowanych warstwach. Sama autorka w wywiadach twierdzi, że jej książki to dzieła dynamiczne, mogące zmienić kontekst w zależności od wiedzy i wrażliwości odbiorcy. Zauważa, że wiele nowych znaczeń, często zaskakujących ją samą, potrafią wydobyć z nich czytelnicy.

Chociaż artystka zaprasza do lektury własnych książek każdego bez względu na wiek, pisząc, że to literatura dla każdego myślącego i wrażliwego człowieka ${ }^{5}$, to kryterium odbiorcy nie daje mi spokoju i zadaję pytanie - dla kogo są jej książki? Pytam i nie znajduję zadowalającej odpowiedzi. Przypuszczam, że osoba wychowana na książkach będących kalkami disnejowskich animacji, a więc zawierających ilustracje ze schematycznymi postaciami, niemalże identycznymi, wstawionymi w kontur, bez odcieni barw, nie mówiąc już o miernej stronie językowej, może mieć problem z odkodowaniem, deszyfracją piękna zawartego w minimalizmie kolorów, dopracowanych kolażach osobliwych tkanin, wykorzystanej symbolice.

Można więc założyć, że obrazowe opowieści I. Chmielewskiej to ważny głos w dyskursie dzieciństwa w kwestii niepokojącego infantylizowania kultury dziecięcej, traktowania dziecka jako „wdzięcznego stworzonka”, „słodkiego elfa” któremu bezrefleksyjnie serwuje się kicz (Klus-Stańska, 2010, s. 27-28). To odpowiedź na estetyczną bylejakość licznych produkcji rynku książki dziecięcej. Stąd twierdzę, że odbiorcę książek I. Chmielewskiej trzeba stworzyć i pomóc mu w odkodowywaniu

4 Artystka otrzymała trzykrotnie nagrodę główną w kategorii New Horizons w konkursie Bologna Ragazzi Award przyznawaną przez Międzynarodowe Targi Książki w Bolonii, największe i najważniejsze na świecie targi książki dla dzieci i młodzieży. W 2011 r. za A House of the Mind: Maum, w 2013 r. za Oczy, w 2020 r. za Kołysankę dla babci. W: https://instytutksiazki.pl/ aktualnosci,2,iwona-chmielewska-z-bolognaragazzi-award,4670.html.

${ }^{5}$ Klatki z wyobraźniq. Z Iwonq Chmielewskq rozmawia Marta Syrwid. W: Znak (2016), grudzień. http://www.miesiecznik.znak.com.pl/klatki-z-wyobraznia/. 
znaczeń. Odwołując się do klasycznej już pozycji Ireny Słońskiej, Psychologiczne problemy ilustracji dla dzieci (Słońska, 1977, s. 105-109), należy przypomnieć, że nie ma czegoś takiego jak wrodzony dobry gust estetyczny. Świadomość estetyczna kształtuje się powoli i wymaga pomocnej dłoni osoby doświadczonej. Picturebooki I. Chmielewskiej jako swoiste dzieła sztuki nie są określane przez samego ich twórcę, one się stają, „dookreślają” w tracie ich kontemplowania przez odbiorcę, dzięki pracy jego wyobraźni. Tak więc proces czytania picturebooków artystki można porównać do koła hermeneutycznego. Za każdym razem czytelnik może inaczej wypełniać luki w tekście czy obrazie, za każdym razem może czerpać z innej puli swoich doświadczeń i przeżyć, wchodzić na inny poziom rozumienia.

Jako pedagog w literaturze pięknej poszukuję kontekstów edukacyjnych, treści sprzyjających wielostronnemu rozwojowi dziecka, praktykowaniu, doświadczaniu przez nie swojego potencjału, przekraczania go, przekraczaniu siebie. Jak zauważył Ryszard Łukaszewicz, w XXI wieku owo „przekraczanie siebie” trudno „przecenić!” „(...) rozumiem edukację jako proces celowego tworzenia, organizowania i reorganizowania okazji do urzeczywistniania się życia ludzkiego w jego humanistycznych treściach” (R. Łukaszewicz, 2020, s. 44). Stąd teza, na której budowałam myślenie: przekraczanie siebie, a więc rozwój, nie byłoby możliwe bez korzystania z wyobraźni jak również zasobów empatii, a to pomaga kształtować odpowiednio dobrana literatura. Książki I. Chmielewskiej, estetycznie mistrzowskie, znane i doceniane w wielu miejscach na świecie, powinny być rozpoznawalne wśród studentów kierunków pedagogicznych, a więc przyszłych nauczycieli, wychowawców. Dzieci mające częsty kontakt z książką wydaną estetycznie, mające pośrednika kroczącego z nim drogą interpretacji, są w stanie kształtować swój gust, rozwijać wyobraźnię, aktywność twórczą, empatię i wrażliwość społeczną. Poddając analizie i interpretacji wybrane książki I. Chmielewskiej, twierdzę, że dysponują one nieorganicznym potencjałem wychowawczym i estetycznym. Widzę w nich unikatowe narzędzie sprzyjające nade wszystko pracy nad rozwojem wyobraźni i empatii dzieci w młodszym wieku szkolnym.

\section{DO CZEGO JEST NAM POTRZEBNA WYOBRAŹNIA I EMPATIA?}

Wyobraźnia jest złożonym procesem poznawczym pomagającym człowiekowi łączyć znane już doświadczenia z tym, co jeszcze rzeczywistym doświadczeniem człowieka nie jest, umożliwia przekształcanie wrażeń i tworzenie ich zupełnie nowych struktur, co jest podstawą twórczego myślenia. Tak więc, wyobraźnia traktowana jest jako źródło twórczych zachowań człowieka, źródło sztuki i jed- 
nocześnie droga do jej poznania. W rozwoju dziecka, jak i jego twórczości rola wyobraźni jest bezsprzeczna. Zaznacza się wykorzystywanie kompensacyjnej funkcji wyobraźni w celu budowania lub podwyższania poczucia własnej wartości dziecka, w procesie autokreacji, budowaniu obrazu siebie, projektowaniu własnej przyszłości. Nie można również przecenić jej znaczenia w procesie społecznych interakcji (Uszyńska-Jarmoc, 2007, s. 36-38). Ryszard Łukaszewicz pisał o edukacji z wyobraźnią - wyobraźnią jako kategorią pojęciową, którą utożsamiamy bezpośrednio ze stymulowaniem zdolności kreatywnych „....) wyobraźnia i wrażliwość są w stanie odmienić nasze zachowanie, tak byśmy nauczyli się mądrze poznawać i szanować nasze siedlisko”, a rolą wychowawcy jest tworzenie „teatru własnej wyobraźni” (Łukaszewicz, 1994, s. 58).

Wyobraźnia służy nam do odkrywania tego, co Alicja z Krainy Czarów zobaczyła po drugiej stronie lustra albo z Małego Księcia baranka, który ukryty jest w skrzynce. To można zobaczyć tylko oczami wyobraźni.

Z kolei empatia jest podstawową umiejętnością wchodzącą w skład inteligencji emocjonalnej, wiąże się z rozumieniem siebie i innych. Obecnie wiemy, że kompetencje emocjonalne są tak samo, a czasem nawet bardziej, pożądane w pracy zespołowej jak wiedza fachowa. Empatia pogłębia poczucie tożsamości, jak również prowadzi do zaangażowania, odpowiedzialności za kogoś, za daną sprawę (Skarga, 1997, s. 152). Empatia jako zdolność do współodczuwania, rozumienia drugiej osoby, jej zachowań, uczuć, którą w swoich rozważaniach Marii Ossowska zastępowała terminami: „współdoznanie”, wrażliwość, współczucie (Ossowska, 2002, s. 56-59), jest podstawową umiejętnością nawiązywania prawidłowych i trwałych relacji międzyludzkich. Empatię można metaforycznie określić jako pomost do drugiego człowieka ${ }^{6}$.

Ryszard Kapuściński w Lapidarium pisał: „Boję się świata bez wartości, bez wrażliwości, bez myślenia. Świata, w którym wszystko jest możliwe. Ponieważ wówczas najbardziej możliwe jest zło?” (Kapuściński, 1990). Powołując się na badania z psychologii rozwojowej wiemy, że młodszy okres szkolny to okres szczególnie sprzyjający pracy nad rozwojem wyobraźni, empatii, wrażliwości;

${ }^{6}$ Krystyna Pankowska w książce Pedagogika dramy. Teoria i praktyka dużo miejsca poświęciła zagadnieniu kształcenia podstawowych dyspozycji człowieka, za które uważa wyobraźnię i empatię. Wskazuje na sięganie w pracy pedagogicznej do metody drama jako wychowania do wartości, poszukiwań moralnych, która to przyczynia się do większej samoświadomości i wrażliwości na innych.

7 Przykłady zmiany funkcjonowania emocjonalnego i społecznego w rozwoju dziecka we wczesnych latach szkolnym: pojawiają się pierwsze przejawy refleksyjności w miejsce impulsywności; następuje zmniejszenie egocentryzmu w miejsce zdolności do przyjmowania perspektywy innych osób; dzieci stają się zdolne do przeżywania dłużej trwających uczuć; rozwija się świadomość 
okres szczególny, o ile dzieci otrzymają odpowiedni pokarm. Jak zaznaczyła Margaret Mead - ,jeśli ma się rozwijać wyobraźnia dziecka, trzeba jej dać czymś się karmić”. Propozycją pokarmu są picturebooki I. Chmielewskiej, jako przykład literatury niebanalnej w obecnej kulturze banału, konsumpcji, masowej produkcji, komercji, licznych płytkich treści zwalniających z myślenia.

W kontekście teoretycznych rozważań nad potrzebą rozwijania empatii i wyobraźni czytelnika, w niespokojnych i trudnych czasach obecnych, trudno nie odnieść się do poetyckiej prozy noblistki Olgi Tokarczuk, która to w Czułym narratorze proponuje kategorię „czułości”, w mojej opinii pokrewną duchowości i empatii. Pozwolę sobie zacytować, do czego autorce służy czułość: „(...) czułość jest bowiem sztuką uosabiania, współodczuwania (...) jest głębokim przejęciem się drugim bytem, jego kruchością, niepowtarzalnością, jego nieodpornością na cierpienie i działanie czasu. (...) Czułość dostrzega między nami więzi, podobieństwa i tożsamości. Jest tym trybem patrzenia, które ukazuje świat jako żywy, żyjący, powiązany ze sobą, współpracujący, i od siebie współzależny. (...) Literatura jest właśnie zbudowana na czułości wobec każdego innego od nas bytu. To jest podstawowy psychologiczny mechanizm powieści” (Tokarczuk, 2020, s. 287-288).

W tych fragmentach widzę namysł autorki nad programem dla literatury najnowszej, literatury, która jest przecież nieustanym sposobem snucia opowieści o świecie i może prowokować do snucia opowieści o sobie. Literatury, która rodzi się z braku i zdziwienia, i żyje dzięki interpretacji, aktywnemu poszukiwaniu, konstruowaniu sensów.

Treści książek I. Chmielewskiej stanowią doskonałe narzędzie wspomagające kształtowanie świadomości estetycznej dziecka, alfabetyzacji wizualnej, która chroni przez bezrefleksyjnym zanurzaniem się we wszechobecnym kiczu kultury masowej żywiącej się nade wszystko komercją. To odpowiedź na migotliwe, szybkie, zmieniające się stale obrazy medialne. Książki artystki sprzyjające wyciszeniu, refleksyjności, wsłuchiwaniu się w to, co przeżywamy, mogą stać się pewną propozycją edukacyjną zachęcającą do kontemplacji, a więc przyglądaniu się czemuś w skupieniu, rozważaniu, w celu odnowy sił duchowych (Pankowska, 2019, s. 15-16). To literatura, która może uwrażliwiać, może prowokować do

społeczna, co ma wyraz w przejmowaniu społecznych reguł postępowania, rozwoju zdolności do zespołowego wykonywania zadań; kształtują się początki autonomii moralnej, co manifestuje się w szacunku dziecka dla reguł wynikających z wzajemnego porozumienia, w poszanowaniu zasady wzajemności oraz uwzględnianiu w swoich ocenach nie tylko czynów, ale i intencji ich sprawców; następuje rozkwit ekspresji, wzbogacanie umiejętności wyrażania własnych przeżyć przez twórczość. W: Appelt, K. (2015). Wiek szkolny. Jak rozpoznać potencjał dziecka? W: A. Brzezińska (red.), Portrety psychologiczne człowieka (s. 271-296). Gdańsk: Gdańskie Wydawnictwo Psychologiczne. 
brania odpowiedzialności, literatura, która swoją „czułą narracją” pomaga stworzyć czułego odbiorcę.

\section{PROPOZYCJE DZIAŁAŃ O CHARAKTERZE EDUKACYJNYM INSPIROWANE KSIĄŻKAMI IWONY CHMIELEWSKIEJ}

W książce $W$ kieszonce artystka intryguje nas prostym pytaniem - „Co Jaś ma w kieszonce?”. Odpowiedzi nie mamy podanej od razu i jednoznacznie, co jest cechą charakterystyczną twórczości artystki, za to wkraczamy w świat obrazów i ich sens możemy generować sami. Każda kieszonka jest inna, wykonana z innego materiału i każda skrywa inną tajemnicę. Zaczynamy zastanawiać się, co Jaś ma w kieszonce, widząc tylko wystający fragment. W ten sposób zakrywanie uruchamia myślenie.

To, co się dzieje w trakcie czytania tej historii, to naturalny dialog dziecka z tekstem literackim i obrazem. Kompozycja tekstu i obrazu sprzyja czytaniu dialogowemu (ang. dialogic reading), interaktywnemu, kiedy można odwrócić role i ze słuchacza stać się czytającym, kiedy można każdą odpowiedź dziecka docenić i zauważyć przejmowanie przez nie coraz większej inwencji, kiedy może ono przemawiać swoim głosem. Naturalne jest szczegółowe przyjrzenie się obrazkom, dotknięcie ich, przybliżenie, oddalenie wzroku, zwrócenie uwagi na fakturę, kolor, odcienie, nasycenie barw, styl ilustracji, druk, format samej książki i spróbowanie określenia tego, nazwania. W przypadku $W$ kieszonce oglądamy kieszonki uszyte z różnych materiałów; to, co się w ich znajduje, to wyszyte nicią najróżniejsze przedmioty. Dzieci powinny uzyskać również informacje o samodzielnym tworzeniu książek przez autorkę, bez używania techniki komputerowej, informacje o pracy, która jest jej pasją.

W metodzie dialogu z tekstem literackim, gdzie utwór jest jego pełnoprawnym uczestnikiem, nie ma określnego schematu pracy z tymże tekstem. Dobrze jest, jak proponują Laura Beth Kelly i Lindsey Moses, zadać dzieciom sugestywne pytanie do przemyślenia podczas czytania, np. „jakie jest przesłanie autora?”, i dać im przestrzeń do mówienia o swoim myśleniu, co je powoduje, ogólnie pozwolić im przejąć inicjatywę (Kelly, Moses, 2018, s. 21-29). Uczniowie nawet pierwszych klas są w stanie prowadzić głębokie dyskusje pod warunkiem zaproponowania im wysokiej jakości literatury, która wymaga przemyślenia, wyciągania wniosków (Kelly, Moses, 2018, s. 22). Aby sprzyjać z kolei wyciąganiu wniosków przez uczniów, ważne jest, aby nauczyciele pozwalali im rozmawiać przez interakcje, a nie traktowali dyskusji jako środka umożliwiającego uczniom wyciąganie 
z góry określonych wniosków. Stąd grupy dyskusyjne dają możliwość zaistnienia przestrzeni do odkrywania alternatywnych sposobów myślenia o tekście. Dorota Klus-Stańska i Marzenna Nowicka w swoich badaniach wskazują na znaczenie rozmowy, dyskusji z dziećmi, do których świetnie przygotowana jest metoda czytania dialogowego (przestrzegają przed pogadanką jako metodą „czekającą” na zaplanowaną z góry odpowiedź) (Klus-Stańska, Nowicka, 2005, s. 88).

Książki I. Chmielewskiej sprzyjają emocjonalnemu angażowaniu się w nie dzieci. Wyobraźnia powiązana z przeżywaniem obrazów, ich kontemplacją, a więc spostrzeganiem treści niejednoznacznych, otwartych, wielopłaszczyznowych, może uruchamiać ekspresję własną. W Kłopocie zastanawiamy się, co też może przypominać pewien kształt, w co możemy go zmieniać, dorysowując do niego kolejne linie, kształty. Te dwie książki (W kieszonce; Kłopot) stanowią doskonałą inspirację do działań w obszarze edukacji plastycznej i technicznej. Pomysłem może być również zakrycie tytułu książek i nieodkrywanie go aż do samego końca spotkania z dziećmi; niech dzieci próbują zatytułować utwór, niech myślą, czy najpierw powinien być tytuł, czy opowieść.

W kolejnych książkach I. Chmielewskiej: Dwoje ludzi; 4 zwykłe miski; O tych którzy się rozwijali; Gdzie jest moja córka, zauważam potencjał do dyskusji z dziećmi nad takimi wartościami, ale i cechami osobowości, jak: wrażliwość, uważność na drugiego człowieka, ale też własne emocje, współpraca, altruizm, dzielenie się dobrami i efektami pracy, akceptacja, wyrozumiałość.

Dwoje ludzi to opowieść o trudach i radościach bycia razem, we dwoje, różnicach i kompromisach. Cztery zwykłe miski skłaniają do refleksji nad nierównościami społecznymi, nierównymi szansami rozwojowymi, potrzebą dzielenia się, myślenia o innych. Sama autorka mówi, że jej zamiarem jest wywołanie refleksji na temat treści ukrytych w obrazach - i tu np. dlaczego jedni mają za dużo, a inni za mało? Podobnie $O$ tych, którzy się rozwijali, niesie przekaz o istocie człowieczeństwa, którą jest czynienie dobra, istocie rozwoju w kontekście społecznej odpowiedzialności i więzi symbolizowanej w opowieści przez nić. Ukazuje ludzką pracę pojmowaną jako służbę społeczną, poczucie obowiązku, inicjatywę, wskazuje na szacunek do owoców ludzkich wysiłków. Gdzie jest moja córka przypomina o istocie miłości, wrażliwości, uważności na innych, akceptacji różnic, niedociągnięć wpisanych w ludzką naturę.

Te utwory są nieco bardziej skomplikowane wizualnie, obrazy odsyłają do sztuki i tradycji kultury europejskiej. Obraz dominuje nad słowem, ale to już nie jeden kształt jak w dwóch poprzednich (W kieszonce; Kłopot), tylko artystyczne kolaże z różnych tworzyw. Symbolika obrazów, podwójne ich znaczenie (np. dwoje ludzi jako kwiat i łodyga, dzień i noc, klucz i zamek), barwa, kolorowa 
czcionka, efekt nakładania się warstw, złudzenie istnienia prawej i lewej strony (Gdzie jest moja córka), operowanie nietypowymi zestawieniami znaczeń, sensów to wybrane wyróżniki stylu artystycznego autorki. Operowanie wizualną metaforą lub symbolem sprawia, że jej książki mogą być czytane na wielu poziomach w zależności od indywidualnych predyspozycji intelektualnych, emocjonalnych, uwarunkowań środowiska i kompetencji kulturowych (znajomości symboli, historii sztuki, odczytywania aluzji itp.)

Zajęcia z dziećmi można rozpocząć od porównania książek, a decyzję wyboru, którą czy które książki przeczytamy, zostawić dzieciom. Intrygującym pomysłem może być również zakrycie tekstu w książkach karteczkami i pozwolenie dzieciom na samodzielne opowiedzenie historii. W przypadku picturebooków I. Chmielewskiej jest to możliwe, gdyż tekst potrafi zmienić kontekst tego, co widzimy, a obraz może odsyłać do nowych znaczeń. W ten sposób przejawia się otwartość dzieła sztuki, jego spotkanie z odbiorcą zakładające między nimi dynamiczny stosunek. Tak na przykład nić, która przebiega przez wszystkie strony O tych, którzy się rozwijali, zmusza czytelnika do dopowiedzenia narracji, wypełnienia luk między szeroką gamą przedstawianych obrazów. Mimika bohaterów sprzyja określaniu ich emocji (Nikolajeva, Scott, 2000, s. 225-239). Dzieci można z kolei prosić o narysowanie własnych emocji wywołanych lekturą.

W Gdzie jest moja córka, można podtrzymać zabawę sugerowaną przez autorkę i starając się czytać wrażeniowo ${ }^{8}$, nie kończyć zdań, a prosić o ich dokończenie dzieci. W ten sposób można przywołać liczne skojarzenia zachowania z danym zwierzęciem, czy też skupić się na kontrastach (np.: radosny jak co/ kto?, smutny jak co/ kto?). Widzimy awers i rewers. Opowieść ta zachęca do wnikliwego, wrażliwego przyglądania się bliskim nam osobom, odkrywania „warstw”, pokładów człowieczeństwa, mocnych i delikatnych stron osobowości, namysłu nad tym, jak często pierwsze wrażenie może być mylące.

Wybrane powyżej historie I. Chmielewskiej opowiedziane obrazami i wyobraźnią skłaniają do rozmowy: Co Wam daje ta historia? Która jej część szczególnie Was zaciekawiła? Jakie emocje wywołał dany obraz? Jak rozumiesz (przykładowe)

8 Czytanie wrażeniowe ma na celu pozostawienie w dziecku licznych wrażeń; to smakowanie literatury wszystkimi zmysłami. Zdaniem Małgorzaty Swędrowskiej, twórczyni metody czytania wrażeniowego, jesteśmy w stanie zarazić dzieci bakcylem czytania wtedy, gdy w atrakcyjny sposób, wychodząc naprzeciw ich potrzebom, będziemy zanurzać je w dobrych tekstach literackich. Picturebooki I. Chmielewskiej, oparte często na stałym koncepcie i zaskoczeniu, zapraszają do zgadywania, dopowiadania wyrazów, ruchu, a więc odbierania historii całym sobą. W: Swędrowska, M. (2014). Czytanie wrażeniowe. Innowacyjny model czytania dzieciom tekstów literackich w przedszkolu i w szkole. Trendy, 2. 
zdania i na ile się z nimi zgadzasz: „Ludzie mogą być jak dwa koła w jednym rowerze (...) Jak okładki książki o miłości, bez których ta opowieść by się rozsypała (...) Jak dwa okna” (Dwoje ludzi). Każde praktycznie zdanie (krótkie, esencjonalne) w wybranych książkach daje liczne możliwości interpretacji, otwartego wypowiedzenia się w odniesieniu do własnych doświadczeń, a szukanie powiązania z obrazem jako nowym materiałem wizualnym pomaga w krytycznym i kreatywnym myśleniu.

Pamiętnik Blumki I. Chmielewskiej niesie z sobą moc dobrej, lecz trudnej pamięci - wspomnień sierot o ich domu prowadzonym przez Janusza Korczaka. Mistrzostwo przekazu I. Chmielewskiej polega na tym, że wspomnienia dziewczynki Blumki to dosłownie epizody, fragmenty, aż się proszące o uzupełnienie, rewitalizację, ożywienie, próbę odtworzenia losów dzieci, ich emocji, marzeń. Dlaczego Chaimek czasem psuje zabawę dzieciom? Dlaczego Aron płacze w nocy? Dlaczego Zygmuś jest ciągle głodny? Co Ci się przypomina, kiedy patrzysz na wybrany obrazek, np. parasol, pod którym doktor stoi z dziećmi, dziecko bujające się na huśtawce, doktor z czereśniami założonymi za uszy, schody stworzone z książek, doktor wieszający pranie? Czy ten obrazek skrywa jakiś sekret? Jakie emocje da się wyczytać z grafik przedstawiających dzieci? To przykładowe obszary do dyskusji na bazie Pamiętnika Blumki, przygotowujące dzieci do radzenia sobie z empatią i czytaniem myśli w prawdziwym życiu. Można w przypadku tej opowieści sięgnąć do dramy jako metody aktywizującej przez przeżywanie. Przykładowo, ćwiczeniem rozwijającym empatię, mogłyby być scenki improwizowane, a więc „wejście w rolę” dzieci z Krochmalnej.

Maria Nikolajeva - badaczka książki obrazkowej, odnosząc się do osiągnięć psychologii poznawczej, twierdzi, że książka obrazkowa nie tylko jest potężnym narzędziem zwiększającym umiejętności wizualne, ale i wspierającym umiejętności emocjonalne dzieci. Zachęca ona do podejmowania prób rozpoznawania emocji w obrazach wizualnych, zwracania uwagi na język ciała postaci, umieszczenie ich w planie rozkładówki, kształt ust, wyraz oczu, ale także kolorystykę (Nikolajeva, 2013, s. 250).

W Pamiętniku Blumki ilustracje dopełniają to, o czym się tylko wspomina w tekście, to, co zostało z dzieciństwa tamtych dzieci, tym bardziej kiedy znamy kontekst, co stało się później (Holokaust). Pamiętnik Blumki to pamięć oddana tak samo dzieciom, jak i ich wielkiemu wychowawcy, który jak czuły ojciec i matka w jednym ukazywał im, czym jest czułość, troska, ufność, szacunek, praca, nadzieja. Przesłanie Janusza Korczaka, jak kochać dziecko, widoczne jest na każdej stronie pamiętnika. Patrzenie na dziecko jako na osobę, w której drzemią potężne pokłady sił, pomoc w ich odkrywaniu i czuwanie, aby dziecko nigdy nie zwątpi- 
ło w swoją wyjątkowość, to zadania dorosłych. Codzienność wysłana dobrymi gestami wobec siebie to esencja miłości wobec drugiego człowieka, to jest to, o czym Blumka chciała pamiętać. Ta opowieść może służyć również do pobudzania myślenia biograficznego niezbędnego w budowaniu tożsamości indywidualnej i społecznej. Fragmenty biografii bohaterów literackich mogą prowokować do refleksji nad przeszłością własną, służyć analizie przemian zachodzących w sobie na przestrzeni lat, prognozowaniu przyszłości (Z. Pietrasiński, 1988, s. 90-112).

Dodatkową „mocą”, którą oferują książki I. Chmielewskiej, jest też moc recyclingu. Materiały, z których powstają kolaże w jej książkach, to zawsze materiały używane, niepotrzebne (np. stare szmatki, nici). Uprawia tym samym artystyczny recykling sentymentalny, nadając przedmiotom drugie życie i zachęcając do równie twórczych działań. Picturebooki artystki sprzyjają wędrówce drogą odkrywania ekologicznego porządku życia.

\section{ZAMIAST ZAKOŃCZENIA}

W tekście podjęłam próbę wskazania ważnych wychowawczo elementów formy i treści książek obrazkowych na przykładzie twórczości literacko-artystycznej I. Chmielewskiej. Wybór obrazkowych książek Iwony Chmielewskiej uzasadniłam nieskończoną możliwością analiz i dyskusji nad znaczeniem ich treści i obrazów. Zaakcentowane przez mnie wartości: wyobraźni, empatii, uważności, ale też dobrej pamięci, refleksyjności, które to uwypuklam w kontakcie z wybranymi książkami, to przypomnienie o znaczeniu wartości estetycznych i moralnych w życiu każdego człowieka. Pomoc dzieciom w nadawaniu wartości mocy wspomnień, a więc poszukiwaniu niekiedy trudnej prawdy (kontekst książki Pamiętnik Blumki), akcentowanie znaczenia empatii, uważności w relacjach międzyludzkich, okazywanie „postawy naznaczonej kulturą serca” (Nowak, 2000-2001, s. 5-9), która nacechowana jest wrażliwością na dobro i piękno, zdolnością kontemplacji, wychodzenia na zewnątrz w celu niesienia pomocy innym (kontekst książek Dwoje ludzi; Cztery zwykłe miski; O tych którzy się rozwijali), a wszystko to prezentowane w urzekającej estetycznie formie, to wskazywanie drogi prowadzącej do wychowania przez sztukę. Warto w tym miejscy odwołać się do idei wychowania przez sztukę, która to stanowi manifest w obronie człowieczeństwa w człowieku współczesnym zagrożonym m.in. przez „przesyty” kultury masowej, dekoncentrujący nadmiar wyborów, płytkich treści, głód konsumpcji, zanik autorytetów. Herbert Read zakładał, że wychowanie przez sztukę ma prowadzić do zrównoważanego rozwoju człowieka, równowagi funkcji emocjonalnych, intelektualnych i motywa- 
cyjno-wolitywnych. Człowiek współczesny został przez niego porównany do ptaka z okaleczonymi skrzydłami. Nie może on płynnie lecieć, ponieważ ma podcięte skrzydło wyobraźni i uczuć, a pozostałe mu dominujące skrzydło intelektu nie pełni należycie swojej funkcji (Read, 1976, s. 296-297).

Zachęcanie, wyszukiwanie, dzielnie się najlepszymi dobrami kultury, w tym rozróżnianie literatury wartościowej od tzw. kiczu (produktu komercyjnego, jaskrawo kolorowego, niedającego pola do pracy wyobraźni czy poszukiwania znaczeń) uważam za obowiązek pedagoga, wychowawcy, opiekuna, jak też rodzica. Chciałabym, aby mój pomysł wyjścia do dzieci z książką artystyczną stał się zachętą do poszukiwania innych o podobnym bogactwie metafor i symboli, tak aby tego typu literatura stała się przedmiotem różnych form edukacji szkolnej i pozaszkolnej.

Jak apelowała Grace Lin, tajwańsko-amerykańska pisarka i ilustratorka dla dzieci, na kanale „Ted Education” w swoim wykładzie Windows and mirrors ${ }^{9}$, dobrze jest poszukiwać książek luster i okien, a więc takich, które zmuszają do autorefleksji (lustra), jak też takich, które pokazują świat, a więc są jak otwarte okno. Picturebooki I. Chmielewskiej mogą być lustrami i oknami.

\section{Bibliografia}

\section{Analizowane książki Iwony Chmielewskiej:}

Chmielewska, I. (2013). Cztery zwykłe miski. Wrocław: Format.

Chmielewska, I. (2014). Dwoje ludzi. Poznań: Media Rodzina.

Chmielewska, I. (2020). Gdzie jest moja córka. Wrocław: Format.

Chmielewska, I. (2013). Kłopot. Warszawa: Wytwórnia.

Chmielewska, I. (2014). O tych, którzy się rozwijali. Poznań: Media Rodzina.

Chmielewska, I. (2015). W kieszonce. Poznań: Media Rodzina.

\section{Literatura naukowa:}

Appelt, K. (2015). Wiek szkolny. Jak rozpoznać potencjał dziecka? W: A. Brzezińska (red.),

Portrety psychologiczne człowieka (s. 271-296). Gdańsk: Gdańskie Wydawnictwo

Psychologiczne.

Arzipe, E., Styles M. (2003). Children Reading Pictures. Interpreting visual texts. New York-London: Routledge Taylor \& Francis Group.

Bader, B. (1976). American picturebooks from Noah's Ark to the Beast Within, New York: Macmillan.

Cackowska, M. (2016). „Emergent literacy”, „visual literacy” i „czytanie dialogowe”.

${ }^{9}$ G. Lin, The windows and mirrors of your Child's Bookshelf https://www.youtube.com/watch?v=_wQ8wiV3FVo. 
Potencjał edukacyjny i emancypacyjny książki obrazkowej w środowisku rodzinnym i przedszkolnym. Problemy Wczesnej Edukacji, 2.

Cackowska, M. (2017). Współczesna książka obrazkowa - pojęcia, typologia, badania, teorie, konteksty, dyskursy. W: M. Cackowska, H. Dymel-Trzebiatowska, J. Szyłak (red.). Ksiq̨żka obrazkowa. Wprowadzenie. Poznań: Instytut Kultury Popularnej.

Emergent Literacy. Children's Books from 0 to 3 (2011). B. Kummerling-Meibauer (red.). Amsterdam-Philadelphia: John Benjamins Publishing Company.

Kapuściński, R. (1995). Lapidarium. Warszawa: Czytelnik.

Kelly, L.B., Moses, L. (2018). Children's Literature That Sparks Inferential Discussions, The Reading Teacher, 1.

Kiefer, B. (2008). What is a Picturebook, Anyway? The Evolution of Form and Substance Through the Postmodern Era and Beyond. W: L.R. Sipei, S. Pantaleo (red.), Postmodern Picturebooks. Play, Parody, and Self-Referentiality. New York-London: Routledge Taylor \& Francis Group.

Klatki z wyobraźnią. Z Iwoną Chmielewską rozmawia Marta Syrwid. W: Znak (2016), grudzień. http://www.miesiecznik.znak.com.pl/klatki-z-wyobraznia/.

Klus-Stańska, D. (2010). Infantylizujący stereotyp nauczycielki wczesnej edukacji. W poszukiwaniu kontekstów i źródeł ukrytego dyskursu „Naszej Pani”. Kultura i Edukacja, 2.

Klus-Stańska, D., Nowicka. M. (2005). Sensy i bezsensy edukacji wczesnoszkolnej. Gdańsk: Harmonia, 2005.

Lin, G. The windows and mirrors of your Child's Bookshelf, https://www.youtube.com/ watch?v=_wQ8wiV3FVo.

Łukaszewicz, R. (1994). Edukacja z wyobraźniq, czyli jak podróżować bez map. Wrocław: Fundacja Wolne Inicjatywy Edukacyjne.

Łukaszewicz, R. (2020). Wrocławska Szkoła Przyszłości PLUS, czyli lepsze jest możliwe. Działania praktyczne, wizje i projekcje nowego-innego-twórczego. Wrocław: Fundacja Wolnych Inicjatyw Edukacyjnych.

Nikolajeva, M. (2013). Picturebooks and emotional literacy. The Reading Teacher, 4.

Nikolajeva, M., Scott C. (2000). The Dynamics of Picturebook Communication. Children's Literature in Education, 4.

Nikolajeva, M., Scott C. (2006). How picturebooks work. New York-London: Routledge Taylor \& Francis Group.

Nowak, M. (2000-2001). Wychowanie do wartościowania w kontekście pluralizmu. Roczniki Nauk Społecznych, t. XXVIII-XXIX, z. 2.

Ossowska, M. (2002). Motywy postępowania: z zagadnień psychologii moralności. Warszawa: Książka i Wiedza.

Pankowska, K. (2000). Pedagogika dramy. Teoria i praktyka. Warszawa: Żak.

Pankowska, K. (2019). Migotliwy obraz świata w świecie obrazów. Kultura i Edukacja, 2. Pietrasiński, Z. (1988). Rozwój z perspektywy jego podmiotu. W: M. Tyszkowa (red.) Rozwój psychiczny człowieka w ciq̨u życia. Zagadnienia teoretyczne i metodologiczne (s. 90-112). Warszawa: PWN.

Read, H. (1976). Wychowanie przez sztukę. Wrocław: Ossolineum.

Skarga, B. (1997). Tożsamość i różnica. Kraków: Znak. 
Słońska, I. (1977). Psychologiczne problemy ilustracji dla dzieci. Warszawa: Wydawnictwo Naukowe.

Spotkanie z Iwoną Chmielewską organizowane w ramach projektu Książki do patrzenia, http://ksiazkidopatrzenia.pl.

Swędrowska, M. (2014). Czytanie wrażeniowe. Innowacyjny model czytania dzieciom tekstów literackich w przedszkolu i w szkole. Trendy, 2.

Tokarczuk, O. (2020). Czuły narrator. Kraków: Wydawnictwo Literackie.

Uszyńska-Jarmoc, J. (2007). Od twórczości potencjalnej do autokreacji w szkole. Białystok: Trans Humana. 